\title{
Risk Factors of Retinopathy of Prematurity in Tertiary Hospital
}

\author{
Nisrina Nabila Raniasari ${ }^{1}$, Reni Prastyani ${ }^{*}$, Risa Etika ${ }^{3}$, Luki Indriaswati ${ }^{2}$ \\ *Corresponding e-mail address: reni-p@fk.unair.ac.id
}

\author{
${ }^{I}$ Medical Study Program, Faculty of Medicine, Universitas Airlangga, Surabaya, Indonesia \\ ${ }^{2}$ Department of Ophthalmology, Faculty of Medicine, Universitas Airlangga, Surabaya, Indonesia \\ ${ }^{3}$ Department of Pediatrics, Faculty of Medicine, Universitas Airlangga, Surabaya, Indonesia
}

\begin{abstract}
Introduction: Retinopathy of prematurity is a potentially blinding disease of the eye due to abnormal retinal vascularization. Gestational age, preterm birth, oxygen therapy, and RBC transfusion are some of the factors associated with ROP. Purpose: This study aims to determine the relation between gestational age, birth weight, duration of oxygen therapy, and RBC transfusion with ROP. Methods: This research is a case-control study using medical records data from Dr. Soetomo General Hospital in the period of January - June 2019. Data is analyzed using logistic regression analysis in SPSS v.25. Results: The case group consists of 22 patients with ROP while the control group consists of 66 patients without ROP. Gestational age $(p=0.030 ; \mathrm{OR}=3.10,95 \% \mathrm{CI}$ $1.113-8.606)$ and duration of oxygen therapy $(p=0.012 ; \mathrm{OR}=3.75,95 \%$ CI $1.342-10.481)$ shows a statistically significant relation with ROP. There is no relation between birth weight $(p=0.098 ; \mathrm{OR}=2.30,95 \% \mathrm{CI} 0.857-6.171)$ and $\mathrm{RBC}$ transfusion $(p=0.881$; $\mathrm{OR}=1.09 ; 95 \%$ CI $0.343-3.480$ ) with ROP. Conclusions: There is a relation between gestational age and duration of oxygen therapy with ROP. Meanwhile, birth weight and RBC transfusion have no relation with ROP.
\end{abstract}

Keywords: Low birth weight; oxygen therapy; preterm birth; RBC transfusion; retinopathy of prematurity

\section{Introduction}

The eye acts as the organ of vision by collecting light and delivering information of what we see to the brain through the optic nerve. The information received is then transformed into a visual image. A visual impairment, which may occur early in life, may prevent the eye from serving its function. (1) It had been reported that preterm infants are susceptible to visual impairment. The risk of visual disturbances and blindness increase in preterm infants (gestational age $<37$ weeks) compared to term-born infants. (2) Prior study reported that infants born with a gestational age of less than and including 25 weeks are at risk for blindness as a longterm poor outcome of extremely preterm birth. (1)

One of the leading causes of vision loss in children is retinopathy of prematurity. (3) Retinopathy of prematurity (ROP) is a disease of the eye characterized by abnormal vascularization. This may occur due to retinal tissue hyperoxia, thus causing down regulation of VEGF (vascular endothelial growth factor) and endothelial cell death. (4) The reduction of VEGF and IGF-1 (insulin-like growth factor 1) disrupts normal angiogenesis and retinal vascularization. (5)

Preterm infants born at $<31$ weeks gestation and low birth weight infants $(<1250 \mathrm{~g})$ are frequently affected by ROP, according to the National Eye Institute. Every year, about 14.000-16.000 infants out of 3.9 million births in the United States suffers from retinopathy of prematurity. (3) One of the main contributors to vision loss that is related to ROP is South East Asia. (6) A Thailand based study reported that as much as $40.7 \%$ preterm infants have some degree of ROP. (7) Meanwhile, 30.3\% infants in Cipto Mangunkusumo Hospital, Jakarta were reported to have retinopathy of prematurity. (8) However, ROP occurrence is not limited to South East Asian Countries. Hong reported a nationwide incidence of 29.8\% in South Korea in a 12-year populationbased study. (9) As much as $27 \%$ of infants in 69 NICUs in Turkey have some degree of ROP. (10) In Iran, the prevalence of retinopathy of prematurity was reported to be $23.5 \%$ in a meta-analysis. (11) Approximately $31.9 \%$ preterm infants with gestational age of $<31$ weeks were reported to have retinopathy of prematurity, according to Holmström who conducted a study in Sweden. (12) 


\section{Method}

This study is an analytical observational study with case-control design to analyze the relation between risk factors (gestational age, birth weight, duration of oxygen therapy, red blood cell transfusion) and retinopathy of prematurity. All low birth weight $(<2500 \mathrm{~g})$ and preterm infants $(<37$ weeks gestation) born in January 2019 - June 2019 in Dr. Soetomo General Hospital who underwent screening for ROP with complete medical records are eligible for the study. The variables collected includes sex, gestational age, birth weight, duration of oxygen therapy, red blood cell transfusion, method of birth, number of births, and existing complications.

Statistical analyses were performed using SPSS v.25. The data collected is analyzed using logistic regression test to determine the relation between risk factors and ROP with significance value of $p<0.05$. Odds ratio (OR) calculation is used to determine the size of association between the variables.

\section{Results}

Among 255 low birth weight and preterm infants born in January 2019 - June 2019 in Dr. Soetomo General Hospital, 28 infants were deceased, thus weren't screened for ROP, 110 infants did not undergo screening as they did not fit into the screening criteria, and 29 infants had incomplete medical records. Only 88 fulfil the inclusion and exclusion criteria, out of which 22 are patients with ROP and 66 are patients without ROP. Most of the ROP patients had stage 1 ROP, found in 11 patients (50\%), 6 patients had stage 2 ROP $(27.3 \%)$. Stage 3 ROP was found in 5 patients $(22.7 \%)$, out of which, one patient presents with pre-plus disease, and another patient with stage 3 ROP presents with plus disease. The schematic distribution of the subjects is as shown in figure 1.

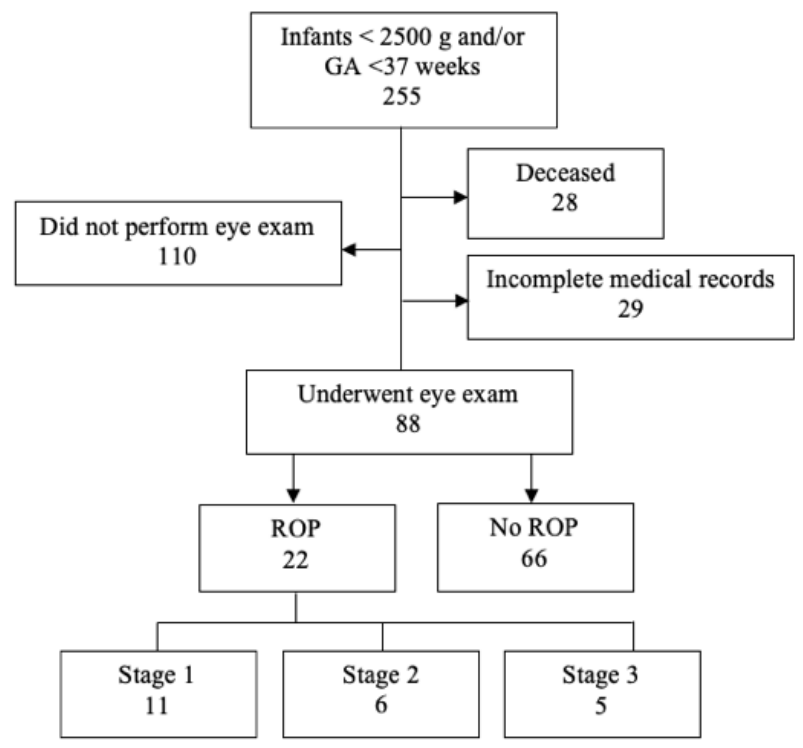

Fig 1. Schematic figure of the subject distribution 
Table 1 shows that the subjects are dominated by female patients $(59.1 \%)$, more than half of the subjects were born at $>32$ weeks gestation (52.3\%), born weighing $\geq 1500 \mathrm{~g}$ (64.8), received oxygen therapy for $<7$ days $(55.7 \%$ ), born by caesarean section (75\%), singleton (75\%), and only $21.6 \%$ received RBC transfusion. Among ROP patients (case group), 68.2\% were born at $\leq 32$ weeks gestation, $50 \%$ were born weighing $<1500 \mathrm{~g}, 68.2 \%$ received oxygen therapy for $\geq 7$ days, and $22.7 \%$ received $\mathrm{RBC}$ transfusion.

Table 1. Subject characteristics

\begin{tabular}{|c|c|c|c|}
\hline Characteristics & ROP $(n=22)$ & $\begin{array}{l}\text { No ROP } \\
(n=66)\end{array}$ & $\begin{array}{l}\text { Total } \\
(n=88)\end{array}$ \\
\hline \multicolumn{4}{|l|}{ Sex, n (\%) } \\
\hline Female & 14 & 38 & $52(59.1)$ \\
\hline Male & 8 & 28 & $36(40.9)$ \\
\hline \multicolumn{4}{|c|}{ Gestational age, $\mathrm{n}(\%)$} \\
\hline$\leq 32$ weeks & 15 & 27 & $42(47.7)$ \\
\hline$>32$ weeks & 7 & 39 & $46(52.3)$ \\
\hline \multicolumn{4}{|l|}{ Birth weight, n (\%) } \\
\hline$<1500 \mathrm{~g}$ & 11 & 20 & $31(35.2)$ \\
\hline$\geq 1500 \mathrm{~g}$ & 11 & 46 & $57(64.8)$ \\
\hline \multicolumn{4}{|c|}{ Duration of oxygen therapy, n (\%) } \\
\hline$\geq 7$ days & 15 & 24 & $39(44.3)$ \\
\hline$<7$ days & 7 & 42 & $49(55.7)$ \\
\hline \multicolumn{4}{|c|}{ RBC transfusion, $\mathbf{n}(\%)$} \\
\hline Yes & 5 & 14 & $19(21.6)$ \\
\hline No & 17 & 52 & $69(78.4)$ \\
\hline \multicolumn{4}{|c|}{ Method of birth, n (\%) } \\
\hline Spontaneous & 1 & 20 & $21(23.9)$ \\
\hline Sectio caesarea & 21 & 45 & $66(75)$ \\
\hline Forceps ekstraksi & 0 & 1 & $1(1.1)$ \\
\hline \multicolumn{4}{|c|}{ Number of births, n (\%) } \\
\hline Single & 17 & 49 & $66(75)$ \\
\hline Multiple & 5 & 17 & $22(25)$ \\
\hline
\end{tabular}

Multiple subjects in this study had multiple comorbidities. As seen on table 2, the most frequent comorbidity was neonatal jaundice found in half of the research subjects. Following that is congenital heart disease (CHD) including atrial septal defect (ASD), ventricular septal defect (VSD), and patent ductus arteriosus (PDA). Eight subjects did not present with any comorbidity.

Among ROP patients, the most common comorbidity is neonatal jaundice in 12 subjects (54.5\%). Followed by RDS in 8 subjects (36.4\%), perinatal asphyxia, CHD and sepsis in 5 subjects (22.7\%) respectively. Suspect sepsis and necrotizing enterocolitis (NEC) were found in 3 patients $(13.6 \%)$ respectively, as well as pneumonia and anemia in 2 patients $(9.1 \%)$ respectively.

Table 2. Present comorbidities among research subjects

\begin{tabular}{llll}
\hline Comorbidities & ROP $(\mathbf{n = 2 2})$ & $\begin{array}{l}\text { No ROP } \\
(\mathbf{n = 6 6 )}\end{array}$ & $\begin{array}{l}\text { Total } \\
(\mathbf{n = 8 8})\end{array}$ \\
\hline $\begin{array}{l}\text { Perinatal asphyxia, n (\%) } \\
\text { Yes }\end{array}$ & 5 & 13 & $18(20.5)$ \\
No & 17 & 53 & $70(79.5)$ \\
\hline
\end{tabular}




\begin{tabular}{|c|c|c|c|}
\hline \multicolumn{4}{|c|}{ CHD, n (\%) } \\
\hline Yes & 5 & 22 & $27(30.7)$ \\
\hline No & 17 & 24 & $61(69.3)$ \\
\hline \multicolumn{4}{|c|}{ Neonatal jaundice, $n(\%)$} \\
\hline Yes & 12 & 32 & $44(50)$ \\
\hline No & 10 & 34 & $44(50)$ \\
\hline \multicolumn{4}{|c|}{ RDS, n (\%) } \\
\hline Yes & 8 & 12 & $20(22.7)$ \\
\hline No & 14 & 54 & $68(77.3)$ \\
\hline \multicolumn{4}{|c|}{ Suspect sepsis, n (\%) } \\
\hline Yes & 3 & 6 & $9(10.2)$ \\
\hline No & 19 & 60 & $79(89.8)$ \\
\hline \multicolumn{4}{|c|}{ Sepsis, n (\%) } \\
\hline Yes & 5 & 10 & $15(17)$ \\
\hline No & 17 & 56 & $73(83)$ \\
\hline \multicolumn{4}{|c|}{ Pneumonia, n (\%) } \\
\hline Yes & 2 & 4 & $6(6.8)$ \\
\hline No & 20 & 62 & $82(93.2)$ \\
\hline \multicolumn{4}{|c|}{ NEC, n (\%) } \\
\hline Yes & 3 & 1 & $4(4.5)$ \\
\hline No & 19 & 65 & $84(95.5)$ \\
\hline \multicolumn{4}{|c|}{ Anemia, n (\%) } \\
\hline Yes & 2 & 7 & $9(10.2)$ \\
\hline No & 20 & 59 & $79(89.8)$ \\
\hline
\end{tabular}

Table 3 shows that gestational age of $\leq 32$ weeks and oxygen therapy for $\geq 7$ days are statistically significant with these results respectively, GA $(p=0.030 ; \mathrm{OR}=3.10,95 \% \mathrm{CI} 1.113-8.606)$ and $\mathrm{O} 2$ therapy $(p=0.012 ; \mathrm{OR}=3.75,95 \%$ CI 1.342-10.481). Meanwhile, birth weight and red blood cell transfusion have a statistically insignificant relation with ROP $(p>0.05)$. The analysis as shown in table 4 included only patients with ROP (case group). Results show that the relation between gestational age and duration of oxygen therapy is not statistically significant $(p=0.448 ; \mathrm{OR}=2.06,95 \%$ CI $0.313-13.574)$.

Table 3. Logistic regression analysis on risk factors of ROP

\begin{tabular}{|c|c|c|c|c|c|c|}
\hline \multirow{2}{*}{ Risk Factors } & \multicolumn{2}{|c|}{ ROP } & \multicolumn{2}{|c|}{ Non ROP } & \multirow[t]{2}{*}{ p value } & \multirow[t]{2}{*}{ OR (CI 95\%) } \\
\hline & $\mathbf{n}$ & $\%$ & $\mathbf{n}$ & $\%$ & & \\
\hline \multicolumn{7}{|l|}{ Gestational Age } \\
\hline$\leq 32$ weeks & 15 & 35.7 & 27 & 64.3 & \multirow{2}{*}{0.030} & \multirow{2}{*}{$\begin{array}{c}3.10(1.113- \\
8.606)\end{array}$} \\
\hline$>32$ weeks & 7 & 15.2 & 39 & 84.8 & & \\
\hline \multicolumn{7}{|l|}{ Birth Weight } \\
\hline$<1500 \mathrm{~g}$ & 11 & 35.5 & 20 & 64.5 & \multirow{3}{*}{0.098} & \multirow{3}{*}{$\begin{array}{l}2.30(0.857- \\
6.171)\end{array}$} \\
\hline$\geq 1500 \mathrm{~g}$ & 11 & 19.3 & 46 & 80.7 & & \\
\hline O2 Therapy & & & & & & \\
\hline$\geq 7$ days & 15 & 38.5 & 24 & 61.5 & \multirow{2}{*}{0.012} & \multirow{3}{*}{$\begin{array}{c}3.75(1.342- \\
10.481)\end{array}$} \\
\hline$<7$ days & 7 & 14.3 & 42 & 85.7 & & \\
\hline \multicolumn{6}{|l|}{ RBC Transfusion } & \\
\hline Yes & 5 & 26.3 & 14 & 73.7 & \multirow[t]{2}{*}{0.881} & \multirow{2}{*}{$\begin{array}{c}1.09(0.343- \\
3.480)\end{array}$} \\
\hline No & 17 & 24.6 & 52 & 75.4 & & \\
\hline
\end{tabular}


Table 4. Bivariate analysis on relation between gestational age and duration of $\mathrm{O} 2$ therapy among case group

\begin{tabular}{ccccccc}
\hline $\begin{array}{c}\text { Gestational } \\
\text { Age }\end{array}$ & \multicolumn{2}{c}{$\mathbf{O 2} \geq \mathbf{7}$ days } & \multicolumn{2}{c}{$\mathbf{O 2}<\mathbf{7}$ days } & p value & OR $(\mathbf{C I}$ 95\%) \\
\hline$\leq 32$ weeks & 11 & 73.3 & 4 & 26.7 & & \\
\hline 32 weeks & 4 & 57.1 & 3 & 42.9 & & 2.448 \\
\hline
\end{tabular}

\section{Discussion}

In this study, ROP patients are dominated by female similar to the findings of prior researches conducted in Indonesia $(13,14)$, but in contrast with a research by Taliwongso et al. $(15)$ In line with a previous study, frequency of ROP patients is higher among infants born at $\leq 32$ weeks gestation. (16) On the contrary, Gaber et al. (17) reported higher frequency of ROP in older infants with gestational age (GA) of $\geq 32$ weeks. The number of subjects with ROP are equally divided within the birth weight category with 11 subjects weighing $<1500 \mathrm{~g}$ and 11 subjects weighing $\geq 1500 \mathrm{~g}$. Most of the patients with ROP were on oxygen therapy for $\geq 7$ days, similar to the findings of a study conducted in Jakarta (18), but opposing to a report by Hakeem et al. (19) Out of 22 patients with ROP, only 5 received RBC transfusion. This result is in line with a study by Rao et al. (20) and opposite of a report by Hengartner et al. (21) Almost all of the patients with ROP were born by caesarean section and only one patient was born spontaneously. This result is in accordance with a research by Dewi et al. (22) Most of the case group subjects were born single, similar to the findings of previous studies $(13,23)$ and in contrast with a study by Akkawi et al. $(24)$

Preterm birth is defined as a live birth before the gestational age reaches a full 37 weeks. (25) It is a condition affected by multiple factors, such as infection, history of preterm birth, premature preterm rupture of membranes, et cetera. (26) Although the cause often remains unidentified in cases of preterm labor. (25) Previous reports have linked increased ROP occurrence with younger gestational age. Lundgren et al. reported a significant decrease in the prevalence of infants needing treatment for ROP to only $0.1 \%$ among infants with 30-31 weeks GA. Meanwhile, the prevalence increased to $45.2 \%$ in the much younger $22-23$ weeks GA infants. (27) Multiple studies have also reported lower mean gestational age in infants with ROP. $(14,28,29)$

Analysis on relation between gestational age and retinopathy of prematurity in this study shows a significant result with $p=0.030$. Infants with a gestational age of $\leq 32$ weeks had 3.10 times greater odds ( $95 \%$ CI 1.113-8.606) to develop ROP compared to those born at $>32$ weeks gestation. Similarly, a cohort study conducted a decade ago in Dr. Soetomo General Hospital Surabaya found significant results and reported gestational age of $<32$ weeks as an independent risk factor for retinopathy of prematurity. (30) The result of this study is also in line with prior studies who reported GA $\leq 32$ weeks as a significant risk factor for ROP. $(13,17,31)$

Low birth weight has long been associated as a risk factor for retinopathy of prematurity and is acknowledged as one of the most important risk factors for the development of ROP. However, it is closely associated with gestational age in premature infants. Therefore, it is still unknown which factor serves a larger contribution for the development of ROP as it is difficult to determine whether the prematurity precedes low birth weight or the other way around. (32)

A worldwide database which collects data from over 1000 NICUs estimated ROP incidence of $33.2 \%$ of all infants weighing $<1500 \mathrm{~g}$ at birth in 2010. (4) Over the years, numerous studies have reported higher ROP incidence or more severe ROP developing in lighter birth weights. $(14,29,33,34)$ This indicates that the 
incidence of ROP increases following the decrease in birth weight. Celebi et al. (29) reported a decrease in mean birth weight related to ROP status. Non-ROP infants have the highest mean birth weight, followed by ROP that does not require laser treatment, and laser treated ROP with the smallest mean birth weight. Binenbaum et al. (33) reported higher mean birth weight in patients with no severe ROP. Likewise, a study in a Tertiary Hospital in Surabaya reported greater mean birth weight in patients without ROP. (14)

This study did not find a significant relation between birth weight and ROP with $p=0.098$. Although odds ratio calculation does show that infants with BW of $<1500 \mathrm{~g}$ have 2.30 times greater chance (95\% CI 0.857-6.171) for developing ROP compared to those born weighing $\geq 1500 \mathrm{~g}$. This result is in accordance with a study conducted in Manado which reported insignificant relation between birth weight and ROP. (15) Contrary to the findings of this research, two previous studies in Saudi Arabia and Iran reported significant relation between birth weight and ROP $(p=0.04, p=0.007)$. $(35,36)$ Even as much as 11.60 times higher odds $(95 \% \mathrm{CI}$ 1.07-126.02) for the occurrence of ROP among infants weighing $<1500 \mathrm{~g}$ at birth in the Saudi Arabian based study. (35)

Premature infants are more prone than term infants to hypoxia. It is a condition in which the level of oxygen needed in tissues for normal organ function is not met. Hypoxia can result from a condition called hypoxemia where there is oxygen insufficiency in the blood. The normal oxygen saturation in infants during the first few hours of life is usually $\geq 88 \%$. In an event where oxygen supply does not match the demand, oxygen supplementation is used to achieve the normal oxygen saturation level. (37)

In this research, the relation between duration of oxygen therapy and ROP appears to be significant with $p=0.012$. Retinopathy of prematurity is 3.75 times (95\% CI 1.342-10.481) more likely to develop in infants who received oxygen therapy for $\geq 7$ days compared to those who received supplementation for less than a week. This finding is in line with previous Indonesian reports conducted in two different cities. The Jakarta and Bali based studies found higher odds for the occurrence of ROP among infants who were on oxygen therapy for $\geq 7$ days with these values respectively $(\mathrm{OR}=11.50 ; 95 \% \mathrm{CI} 4.51-29.13$, OR=11.0; 95\% CI 3.20-37.20). $(18,38)$ The mode of ventilation and oxygen fraction may also contribute to the development of retinopathy of prematurity. (38). Although Munadzilah et al. (39) concluded otherwise and reported insignificant difference between the use of lower oxygen fraction (21-30\%) and 100\% oxygen concentration towards retinopathy of prematurity outcome.

Decrease in hemoglobin $(\mathrm{Hb})$ levels during the first few weeks of life is a physiologic occurrence in newborn. In term infants, the $\mathrm{Hb}$ value usually stays above $10 \mathrm{~g} / \mathrm{dL}$ at age 10 to 12 weeks. (40) Strauss et al. (40) also observed that hemoglobin value in preterm infants with heavier birth weight is higher compared to those with lighter birth weight. Some organs or systems including the hematopoietic system may be underdeveloped in premature birth due to the shortened gestational age, thus resulting in anemia. Preterm infants typically undergo numerous laboratory testing that require phlebotomy which may contribute to blood loss. (41) $\mathrm{RBC}$ transfusion is given to preterm infants if deemed necessary with the goal of increasing oxygen transport to the organs. (42)

This study found non-significant relation between RBC transfusion and ROP with $p=0.881$. Infants who received RBC transfusion have 1.09 times (95\% CI 0.343-3.480) higher odds for the occurrence of ROP compared to those who never received red blood cell transfusion. Badriah et al. (18) and Hengartner et al. (21) who previously conducted a study in Indonesia and Switzerland respectively reported similar findings where $\mathrm{RBC}$ transfusion is not related to the development of $\operatorname{ROP}(p=0.327, p=0.179)$. In contrast, two previous studies reported significant relation between red blood cell transfusion and retinopathy of prematurity. $(28,35) \mathrm{Wu} e t$ 
al. (28) who conducted a study in China reported 4.17 times greater odds for the occurrence of ROP in infants who received red blood cell transfusion.

Bivariate analysis using chi-square test found no relation between gestational age and duration of oxygen therapy $(p>0.05)$. By odds ratio calculation in the analysis shown in table 3 , duration of oxygen therapy possess greater risk for the development of ROP compared to gestational age. However, the need to use oxygen supplementation is also affected by younger gestational age itself. As infants who are born prematurely have yet to complete a full-term pregnancy, the respiratory organ and system are often not sufficient to support the respiratory needs of a premature infant. (43) Odds ratio calculation between gestational age and duration of oxygen therapy, as seen in table 4 , shows that infants born at $\leq 32$ weeks gestation are 2.06 times (95\% CI $0.313-13.574)$ more likely to receive oxygen supplementation for $\geq 7$ days. Duration of oxygen supplementation is adjusted to the infant's clinical condition. If $\mathrm{SpO} 2$ level stays $>90 \%$ and the infant does not present with alarming clinical signs, oxygen can be disconnected gradually. (37) For infants with CPAP ventilation, discontinuation of support is based on multiple factors, such as infant's weight, chronologic age, clinical condition, and breathing stability. (44)

\section{Conclusion}

In conclusion, the relation between gestational age and ROP, as well as between duration of oxygen therapy and ROP is statistically significant. However, there is no relation between birth weight and ROP, and $\mathrm{RBC}$ transfusion and ROP. Also, there is no relation between gestational age and duration of oxygen therapy among ROP patients. Using a larger sample with a longer period of research, as well as more variations in subject characteristics and risk factors are suggested.

\section{Acknowledgements}

The authors are grateful for the support and help of the staffs at the medical records center at Dr. Soetomo General Hospital. We would also like to express our gratitude to the doctors and staffs at the Eye Department of the Outpatient Installation of Dr. Soetomo General Hospital for the assistance.

\section{References}

1. Jarjour I. Neurodevelopmental Outcome After Extreme Prematurity: A Review of the Literature. Pediatr Neurol. 2015;52(2):14352 .

2. Hirvonen M, Ojala R, Korhonen P, Haataja P, Eriksson K, Gissler M, et al. Visual and Hearing Impairments After Preterm Birth. Pediatrics. 2018;142(2):e20173888.

3. National Eye Institute. Retinopathy of Prematurity | National Eye Institute. 2019.

4. Freitas A, Mörschbächer R, Thorell M, Rhoden E. Incidence and risk factors for retinopathy of prematurity: a retrospective cohort study. Int J Retin Vitr. 2018;4(20).

5. Kumar VH. Pathogenesis and Management of Retinopathy of Prematurity in Premature Infants. Pediatr Neonatal Nurs. 2015;2(2):62-9.

6. Gilbert C, Blencowe H. Retinopathy of prematurity: it is time to take action. Community Eye Heal J. 2017;30(99):45-8.

7. Thitiratsanont U, Wutthiworavong B, Keyurapan B, Amphornphruet A, Supangkasen I, Saowaprut C. Screening for Retinopathy of Prematurity in Queen Sirikit National Institute of Child Health: Bangkok, Thailand. Thai J Ophthalmol. 2011;25(1):10-6.

8. Adriono GA, Elvioza, Sitorus RS. Screening for retinopathy of prematurity at Cipto Mangunkusumo Hospital, Jakarta, Indonesia - a preliminary report. Acta Medica Litu. 2006;13(3):165-70.

9. Hong EH, Shin YU, Bae GH, Choi YJ, Ahn SJ, Sobrin L, et al. Nationwide incidence and treatment pattern of retinopathy of prematurity in South Korea using the 2007-2018 national health insurance claims data. Sci Rep. 2021;11(1451):1-2.

10. Bas AY, Demirel N, Koc E, Isik D, Hirfanoglu I, Tunc T. Incidence, risk factors and severity of retinopathy of prematurity in 
Turkey (TR-ROP study): a prospective, multicentre study in 69 neonatal intensive care units. Br J Ophthalmol. 2018;102(12):1711-6.

11. Azami M, Jaafari Z, Rahmati S, Farahani A, Badfar G. Prevalence and risk factors of retinopathy of prematurity in Iran: a systematic review and meta-analysis. BMC Ophthalmol. 2018;18(1):83.

12. Holmström G, Tornqvist K, Al-Hawasi A, Nilsson $\AA$, Wallin A, Hellström A. Increased frequency of retinopathy of prematurity over the last decade and significant regional differences. Acta Ophthalmol. 2018;96(2):142-8.

13. Leng Y, Huang W, Ren G, Cai C, Tan Q, Liang Y, et al. The Treatment and Risk Factors of Retinopathy of Prematurity in Neonatal Intensive Care Units. BMC Ophthalmol. 2018;18(1):1-8.

14. Harahap A, Utomo MT, Etika R. Predictive Model for Retinopathy of Prematurity in a Tertiary Hospital in Indonesia. Int J Res Publ. 2021;89(1):89-100.

15. Taliwongso DG, Sumual V, Saerang JSM. Hubungan Faktor Risiko Dengan Terjadinya Retinopathy of Prematurity (ROP). J Kedokt Klin. 2016;1(1):116-25.

16. Bhuiyan ANH, Mannan M, Dey SK, Choudhury N, Shameem M, Shahidullah M. Frequency and Risk Factors for Retinopathy of Prematurity in Very Low Birth Weight Infants in NICU, BSMMU. TAJ J Teach Assoc. 2019;32(1):54-61.

17. Gaber R, Sorour OA, Sharaf AF, Saad HA. Incidence and Risk Factors for Retinopathy of Prematurity (ROP) in Biggest Neonatal Intensive Care Unit in Itay Elbaroud City, Behera Province, Egypt. Clin Ophthalmol. 2021;15:3467-71.

18. Badriah C, Amir I, Elvioza, Ifran EK. Prevalence and Risk Factors of Retinopathy of Prematurity. Paediatr Indones. 2012;52(3):138-44.

19. Hakeem AA, Mohamed GB, Othman MF. Retinopathy of Prematurity: A Study of Prevalence and Risk Factors. Middle East Afr J Ophthalmol [Internet]. 2012;19(3):289. Available from: http://www.meajo.org/text.asp?2012/19/3/289/97927

20. Rao K, Purkayastha J, Hazarika M, Chaitra R, Adith KM. Analysis of Prenatal and Postnatal Risk Factors of Retinopathy of Prematurity in a Tertiary Care Hospital in South India. Indian J Ophthalmol. 2013;61(11):640-4.

21. Hengartner T, Adams M, Pfister RE, Snyers D, McDougall J, Waldvogel S, et al. Associations between Red Blood Cell and Platelet Transfusions and Retinopathy of Prematurity. Neonatology. 2020;117(5):562-8.

22. Dewi R, Tuhusula R, Rohsiswatmo R. Skrining Retinopathy of Prematurity di Rumah Sakit dengan Fasilitas Terbatas. Sari Pediatr. 2012;14(3):185-90.

23. Mehmet S, Fusun A, Sebnem C, Ozgur O, Gulten E, Taylan OA, et al. One-year Experience in the Retinopathy of Prematurity: Frequency and Risk Factors, Short-term Results and Follow-up. Int J Ophthalmol. 2011;4(6):634-40.

24. Akkawi M, Shehadeh M, Shams A, Al-Hardan D, Omar LJ, Almahmoud O, et al. Incidence and Risk Factors of Retinopathy of Prematurity in Three Neonatal Intensive Care Units in Palestine. BMC Ophthalmol. 2019;19(1):189.

25. World Health Organization. Preterm Birth. 2018.

26. Suman V, Luther E. Preterm Labor. Treasure Island (FL): StatPearls Publishing; 2021.

27. Lundgren P, Kistner A, Andersson E, Pupp I, Holmström G, Ley D, et al. Low Birth Weight Is a Risk Factor for Severe Retinopathy of Prematurity Depending on Gestational Age. PLoS One. 2014;9(10):e109460.

28. Wu T, Zhang L, Tong Y, Qu Y, Xia B, Mu D. Retinopathy of Prematurity Among Very Low-Birth-Weight Infants in China: Incidence and Perinatal Risk Factors. Investig Ophthalmol Vis Sci. 2018;59(2):757-63.

29. Celebi AR, Petriçli İS, Hekimoglu E, Demirel N, Bas AY. The Incidence and Risk Factors of Severe Retinopathy of Prematurity in Extremely Low Birth Weight Infants in Turkey. Med Sci Monit. 2014;20:1647-53.

30. Utomo MT, Harahap A, Etika R. Incidence and Risk Factors of Retinopathy of Prematurity (Rop): a Single Center Study in a Tertiary Center in Indonesia. Int J Res Publ. 2021;87(1):266-77.

31. Yadav R, Gupta S, Shrestha JB, Yadav R, Yadav TBS. Perinatal Risk Factors for Retinopathy of Prematurity in Preterm and Low Birth Weight Neonates. Nepal J Ophthalmol. 2020;12(23):32-8.

32. Petriçli İS, Kara C, Işı D, Demirel N, Baş A. Effect of birth weight on retinopathy of prematurity in discordant twin pairs. Indian J Ophthalmol. 2019;67(6):806-10.

33. Binenbaum G, Ying G, Quinn G, Dreiseitl S, Karp K, Roberts RS, et al. A Clinical Prediction Model to Stratify Retinopathy of Prematurity Risk Using Postnatal Weight Gain. Pediatrics. 2011;127(3):607-14.

34. Gonski S, Hupp S, Cotten CM, Clark R, Laughon M, Watt K, et al. Risk of development of treated retinopathy of prematurity in very low birth weight infants. J Perinatol. 2019;39:1562-8.

35. Al-Qahtani B, Al-Otaibi M, Alabdulajabbar K, Selayem N Bin, Alshehri W, Omair A, et al. Retinopathy of Prematurity Incidence and Risk Factors in a Tertiary Hospital in Riyadh, Saudi Arabia. Middle East Afr J Ophthalmol. 2019;26(4):235-9.

36. Rasoulinejad S, Montazeri M. Retinopathy of Prematurity in Neonates and its Risk Factors: A Seven Year Study in Northern Iran. Open Ophthalmol J. 2016;10:17-21.

37. World Health Organization. Oxygen Therapy for Children. Geneva: World Health Organization; 2016. 4-29 p.

38. Wulandari PV, Kardana IM, Sutyawan IWE. Durasi, fraksi dan cara pemberian oksigen sebagai faktor risiko terhadap retinopathy of prematurity (ROP) pada bayi kurang bulan di bagian Neonatologi RSUP Sanglah. Medicina (B Aires). 2018;49(2):67-70.

39. Munadzilah S, Dewi R. Laporan kasus berbasis bukti Mortalitas dan Morbiditas pada Bayi Prematur dengan Resusitasi Menggunakan Oksigen Konsentrasi Rendah Mortality and Morbidity of Preterm Neonates With Resuscitation Using Low Oxygen concentration. Sari Pediatr. 2017;19(3):166-71.

40. Strauss R. Anaemia of Prematurity: Pathophysiology \& Treatment. Blood Rev. 2010;24(6):221-5.

41. Hasanbegovic E, Cengic N, Hasanbegovic S, Heljic J, Lutolli I, Begic E. Evaluation and Treatment of Anemia in Premature Infants. Med Arch. 2016;70(6):408-12. 
42. Kalteren WS, Mebius MJ, Verhagen EA, Tanis JC, Kooi EMW, Bos AF. Neonatal Hemoglobin Levels in Preterm Infants Are Associated with Early Neurological Functioning. Neonatology. 2021;118(5):593-9.

43. Ali SKM, Mohammed N, Qureshi N, Gupta S. Oxygen therapy in preterm infants: recommendations for practice. Paediatr Child Heal (United Kingdom) [Internet]. 2021;31(1):1-6. Available from: https://doi.org/10.1016/j.paed.2020.10.001

44. Bamat N, Jensen E, Kirpalani H. Duration of continuous positive airway pressure in premature infants. Semin Fetal Neonatal Med. 2016;21(3):189-95. 